Int. J. Agril. Res. Innov. Tech. 10(2): 29-34, December 2020 Available online at https://ijarit.webs.com DOI: https://doi.org/10.3329/ijarit.v10i2.51573

https://www.banglajol.info/index.php/IJARIT

\title{
Various inputs applied for growing sweet potato in the tidal swamp area of south Borneo of Indonesia
}

\author{
Y. Widodo ${ }^{1^{*}}$, S. Wahyuningsih ${ }^{2}$, R.D. Purwaningrahayu ${ }^{2}$, Nuryati ${ }^{3}$ and M.J. Mejaya ${ }^{3}$ \\ Received 23 May 2020, Revised 14 September 2020, Accepted 24 December 2020, Published online 31 December 2020
}

\begin{abstract}
A B S T R A C T
In South Borneo, sweet potato baking is very good market and has to be shipped from Java for fulfilling the demand of the people. Preparation of sweet potato as additional food is only simple by put in oven, so it is sold fresh from the oven. In 2015, description of area mainly physical and chemical aspects were undertaken to provide adequately data. Analysis of soil sample was done for the parameters of $\mathrm{pH}, \mathrm{C}$ organic as well as $\mathrm{N}, \mathrm{P}$ and $\mathrm{K}$. Based on this analysis, the treatment was designed based on practical work. Apex vine cutting of several sweet potato varieties were taken from ILETRI to Borneo during 2016 and 2017. In 2017, two varieties were used as the main plot, and five inputs were determined as subplot. Therefore, ten combination treatments were laid down in three replications, in the plot size of $6.0 \mathrm{~m} \times 5.0 \mathrm{~m}$. Planting distance of sweet potato was $100 \mathrm{~cm} \mathrm{x} 25 \mathrm{~cm}$. During 2017, planting was done at February and harvesting was undertaken on July. Growth and yield components were analyzed by statistical procedure by using MSTATC. Statistical analysis indicated that there was not significantly affected by interaction between variety and agronomic inputs as well. However, both main and subplot were separately affected growth and yield. ILETRI variety Beta3 gave better yield with agronomic input1 able to obtain 15.39 $t_{\text {ha }}{ }^{-1}$. However, the increase of agronomic input did not follow the increase of tuber yield.
\end{abstract}

Keywords: Sweet potato, Tidal swamp area, Farming in south Borneo.

${ }^{1}$ Senior Agronomist of Indonesian Legume and Tuber Crops Research Institute (ILETRI) P.O. Box 66 Malang 65101, Indonesia. ${ }^{2}$ Junior Agronomist of Indonesian Legume and Tuber Crops Research Institute (ILETRI) P.O. Box 66 Malang 65101, Indonesia.

${ }^{3}$ Junior Agronomist and Professor Research of Plant Breeder at ILETRI P.O. Box 66 Malang 65101, Indonesia.

*Corresponding author's email: yudi_atas@yahoo.com (Y. Widodo)

Cite this article as: Widodo, Y., Wahyuningsih, S., Purwaningrahayu, R.D., Nuryati and Mejaya, M.J. 2020. Various inputs applied for growing sweet potato in the tidal swamp area of south Borneo of Indonesia. Int. J. Agril. Res. Innov. Tech. 10(2): 29-34. https://doi.org/10.3329/ijarit.v10i2.51573

\section{Introduction}

Among the food crops, sweet potato is the fifth important source of carbohydrate in Indonesia (BPS, 2017). Aside roots with various diversities of colors indicating different qualities, namely yellow till orange high in Beta carotine and purple high in antocyanine, as well as vitamin $\mathrm{C}$ and any other minerals (Firon et al., 2009). Sweet potato is additional food very popular in Indonesia, including in South Borneo. Sweet potato baking is very good market and has to be shipped from Java for the people in Borneo. Preparation of sweet potato as additional food is only simple by put in oven, so it is sold fresh from the oven. Generally the price of sweet potato fresh is around Rp. 27.500/kg. This price is consider interesting for the people around South of Borneo. Therefore growing sweet potato in South Borneo is an opportunity, because market is really available. Moreover, sweet potato in South Borneo is developing in the levees of canal to be harvested for vine cutting as vegetables. However in Negara sweet potato can be grown for tuberous root yield after four months. It is grown in the area of swamp after water dried, so land occur then sweet potato is planted on the huge of ridges smeared by mud. The local cultivar produced a higher yield one or two tuberous root per plant. However, farmers did not grow in larger area, due to limitation of planting material as well as it was done merely by their own labor.

Indeed in South Borneo is a lot of land available, however most of abundaned lands are catagoried into tidal swamp area. Consequently sweet potato was not grown in the area, due to assumption of unsuitability. However, in Papua New Guinea sweet potato is grown by farmers in the big mound or higher ridges to save from tidal, and able to have tuber yield approximately $1-2 \mathrm{~kg}$ plant $^{-1}$ harvested in 6 to 8 months after planting 
(Bayliss-Smith et al., 2017). In the swamp of Papua New Guinea, sweet potato is grown for human food as well as pig feeding for non edible tuberous root and vines. Sweet potato vines in some growing areas are prunned, then picking up to be used for planting material and the remaining are used as animal feed. However, in tidal swamp area of South Borneo water and soil are sometimes very acid at $\mathrm{pH} 2.5-3.5$ so very difficult to grow food crops including sweet potato in such areas (Anna et al., 2015). The vigorous vines are indicated by several varieties which indeed the yield is still questionable until harvesting. To build higher and bigger ridges are possible in order to provide aeration so well drainage resulting water logging can be avoided. Hilling up properly was undertaken to protect sweet potato from weevil. By intensive management of agriculture, the tidal swamp area will be more important and preparation of land is more difficult compared to ordinary lands (Alvernas et al., 2014; Virendra, 2014).

\section{Materials and Methods}

\section{Site description physical and chemical properties}

The three consequtive years since 2015, 2016 and 2017 were the vintage of growing sweet potato in the sites were villages under subdistrict of Wanaraya district of Barito Kuala province of South Borneo, Indonesia. In 2015, description of area mainly physical and chemical aspects are undertaken to provide adequately data. Analysis of soil sample, manure and liquid waste as fertilizer were done in $\mathrm{pH}, \mathrm{C}$ organic as well as $\mathrm{N}$, $\mathrm{P}$ and $\mathrm{K}$ at laboratory of plant \& soil of ILETRI. Based on this analysis then treatment are designed based on practical work.

\section{Sweet potato grown in tidal swamp land}

Apex vine cutting of two sweet potato varieties were taken from ILETRI to Borneo in 2016, namely Antin2, Beta3 and compared to Local. In 2016, the split plot design at three resplications, main plot were three canopy management $(\mathrm{C} 1=$ mulching and canopy did not care, $\mathrm{C}_{2}=$ canopy lifting twice and $\mathrm{C}_{3}=$ canopy were prunned $30 \%$ at $2.5-3.0$ months) sub plot were four fertilizer application ( $\mathrm{F} 1=5 \mathrm{t} \mathrm{ha}^{-1}$ manure, $\mathrm{F} 2=300 \mathrm{~kg} \mathrm{ha}^{-1}$ Phonska, and $\mathrm{F}_{3}=500 \mathrm{l} \mathrm{ha}^{-1}$ $\mathrm{KNO}_{3}$ and $\mathrm{F}_{4}=\mathrm{F}_{1}+\mathrm{F}_{2}+\mathrm{F}_{3}$ ). The site was in lower water regime of Kolam Makmur and Sidomulyo district of Wanaraya type C. In 2017, the site was at village Simpangjaya, a split plot design, two varieties were used as the main plot, and five inputs were determined as subplot (Table 1). Therefore ten combination treatments were laid down in three replication, in the plot size of $6.0 \mathrm{x}$ $5.0 \mathrm{~m}$. Planting distance of sweet potato was 100 $\mathrm{cm} \times 25 \mathrm{~cm}$. During 2017, planting was done at February and harvesting was undertaken on July. Land preparation was done by hand tractor. Plowing twice were undertaken horizontal and vertically to provide adequate growth. Ridging then was done by hoe to obtain height standard. At two and half months after planting hilling up was done to avoid from sweet potato weevil. Insecticide in a form of Furadan $3 \mathrm{G} 25 \mathrm{~kg} \mathrm{ha}^{-1}$ was applied at 2 months after planting. Harvest was done at 4 months, and observations were made during harvest. Growth and yield components were analyzed by statistical procedure by using MSTATC, if it was significantly different then continued by mean separation test by using Least Significant Difference at probability $5 \%$.

Table 1. Treatment structure of tehnological inputs of sweet potato in Batola South of Borneo, 2017.

\begin{tabular}{|c|c|c|c|c|c|}
\hline \multirow{2}{*}{$\begin{array}{l}\text { Technological } \\
\text { items }\end{array}$} & \multicolumn{5}{|c|}{ Technological Inputs } \\
\hline & Farmer & Input1 & Input2 & Input3 & Input4 \\
\hline Weeding & $\begin{array}{l}\text { Farmer } \\
\text { practice }\end{array}$ & $\begin{array}{l}\text { Applying } \\
\text { mulch }\end{array}$ & $\begin{array}{c}\text { Contact } \\
\text { Herbicide } \\
\text { (Gramoxone) }\end{array}$ & $\begin{array}{l}\text { Systemic } \\
\text { Herbicide } \\
\text { (Roundup) }\end{array}$ & $\begin{array}{c}\text { Systemic + } \\
\text { Contact } \\
\text { Herbicide }\end{array}$ \\
\hline Soil Tillage & $\begin{array}{l}\text { Farmer } \\
\text { practice }\end{array}$ & Ridging & Ridging & Ridging & Ridging \\
\hline Manure & $\begin{array}{l}\text { Farmer } \\
\text { practice }\end{array}$ & $10.0 \mathrm{t} \mathrm{ha}^{-1}$ & $7 \cdot 5 \mathrm{t} \mathrm{ha}^{-1}$ & 5.0 t ha $^{-1}$ & $2.5 \mathrm{t} \mathrm{ha}^{-1}$ \\
\hline Lime (dolomite) & $\begin{array}{l}\text { Farmer } \\
\text { practice }\end{array}$ & $\begin{array}{l}500 \mathrm{~kg} \mathrm{ha}^{-1} \\
\text { applied at top } \\
\text { of ridges }\end{array}$ & $\begin{array}{l}1000 \mathrm{~kg} \mathrm{ha}^{-1} \\
\text { applied at top } \\
\text { of ridges }\end{array}$ & $\begin{array}{l}1500 \mathrm{~kg} \mathrm{ha}^{-1} \\
\text { applied at top } \\
\text { of ridges }\end{array}$ & $\begin{array}{l}2000 \mathrm{~kg} \mathrm{ha}^{-1} \\
\text { applied at top } \\
\text { of ridges }\end{array}$ \\
\hline $\begin{array}{l}\text { Phonska } \\
\left(\mathrm{NPK}=15^{+15+15)}\right.\end{array}$ & $\begin{array}{l}\text { Farmer } \\
\text { practice }\end{array}$ & $100 \mathrm{~kg} \mathrm{ha}^{-1}$ & $200 \mathrm{~kg} \mathrm{ha}^{-1}$ & $400 \mathrm{~kg} \mathrm{ha}^{-1}$ & $600 \mathrm{~kg} \mathrm{ha}^{-1}$ \\
\hline $\begin{array}{l}\text { Pest and disease } \\
\text { control }^{*} \text { ) }\end{array}$ & $\begin{array}{l}\text { Farmer } \\
\text { practice }\end{array}$ & $\begin{array}{c}\text { As } \\
\text { recommended }\end{array}$ & $\begin{array}{c}\text { As } \\
\text { recommended }\end{array}$ & $\begin{array}{c}\text { As } \\
\text { recommended }\end{array}$ & $\begin{array}{c}\text { As } \\
\text { recommended }\end{array}$ \\
\hline
\end{tabular}




\section{Results and Discussion}

\section{Site description, physical and chemical properties}

From the field survey of 2015, basically soil type of Batola was dominated by Alluvial and the remaining was Organosol around one third portion. According to Anna et al. (2015) based on their exploration of Batola Soil by Map with scale of $1: 100.000$, showed that there are two types of soil, Organosols 101.900 ha (34\%) and Alluvials 191.390 ha (64\%). The Alluvials had almost largely utilized for cultivation, and the some Organosols Glei humus were continuously inundated areas. The soils in general has high clay content ( $57.8 \%$ clay). This land is a great area for tidal farm in Batola. The results of overlapping maps of land use and land capability map showed that Alluvial was generally cultivated area for rice farming. Other than agricultural lands, there were also land overgrown with shrub, including keramunting, ferns, trees Galam, tall grass, acacia, rush (Eleocharis dulcis), and other creeping plants. Those plants were usually found in all tidal swamp area of South Borneo, precisely in areas that were not used for agriculture. Tidal swamp of Barito Kuala (Batola) is flat area, with easily logged by water from river and sea. Consequently tidal swampland was very suitable for growing rice, with potential to landraces (Purnomo et al., 2008). Sweet potato is grown after rice harvested by utilizing straw from rice to be kept as mulch as well as to build into the ridges. According to Widjaja-Adhi (1986), based on tipe of tidal swamp can be catagoried into four type namely $\mathrm{A}=$ land always submerge eventhough by minimum tidal. $\mathrm{B}=$ land only tide by maximum tidal, $\mathrm{C}=$ land never flooded even by minimum tidal, and land area was $50 \mathrm{~cm}$ above water, $\mathrm{D}=$ land never flooded by tidal and land area was $>50 \mathrm{~cm}$ above water. In Table 2 indicated chemical properties of three sites namely Kolam Makmur, Sidamulya and Simpangjaya as well that mostly $\mathrm{pH}$ were $4.4 ; 4.3$ and 5.1, respectively. In case of Simpangjaya, in 2017 soil pH was 6.0 and higher than did in the same site 2015 namely $\mathrm{pH}$ was 5.1, due to application of lime regularly. The increase of soil $\mathrm{pH}$ was not affected merely by application of lime, but it was from ash coincided with manure applied. In term of $\mathrm{C}$ organic the site of Simpangjaya $>3 \%$ was higher than did of Kolam Makmur 1.15 and Sidamulya 1.00. The reason of Simpangjaya as site for sweet potato due to $\mathrm{pH}$ was 6.0 (Anthony and Ramkisson, 2011). So far tuber yield of sweet potato in tidal swampland was very easy to deteriorate, although in a week after harvest some of tuber performing poor storability. This phenomenon was not common in the other area, due to might be grown under high moisture content with low $\mathrm{pH}$ as well.

Table 2. Results of soil analysis in study area of Barito Kuala (Batola) South of Borneo during 20152017.

\begin{tabular}{|c|c|c|c|c|c|}
\hline Treatments & $\begin{array}{c}\mathrm{pH} \mathrm{H} 2 \mathrm{O} \\
1: 5\end{array}$ & $\begin{array}{c}\mathrm{N} \\
\text { Kjeldahl \% }\end{array}$ & $\begin{array}{c}\mathrm{P}_{2} \mathrm{O}_{5} \\
\text { Bray } 1 \text { ppm }\end{array}$ & $\begin{array}{c}\mathrm{K} \\
\mathrm{NH}_{4} \mathrm{OAc} \mathrm{pH} \\
\text { 7.0 } \mathrm{Cmol}^{+} / \mathrm{kg}\end{array}$ & $\begin{array}{c}\text { C-Organic } \\
\text { W \& Black (\%) }\end{array}$ \\
\hline $\begin{array}{l}\text { Kolam } \\
\text { Makmur }\end{array}$ & 4.4 & 0.38 & 61.7 & 0.54 & 1.15 \\
\hline Sidamulya & $4 \cdot 3$ & 0.34 & 31.8 & 0.49 & 1.00 \\
\hline $\begin{array}{l}\text { Simpangjaya } \\
\text { Farmer } 2015\end{array}$ & 5.1 & 0.23 & 41.4 & 0.38 & 4.06 \\
\hline $\begin{array}{l}\text { Simpangjaya } \\
\text { Farmer } 2017\end{array}$ & 6.0 & 0.37 & 222.0 & 1.10 & $3 \cdot 33$ \\
\hline Input1 & 5.9 & 0.35 & 115.0 & 0.56 & 3.23 \\
\hline Input2 & 5.9 & 0.36 & 136.0 & 0.60 & 3.13 \\
\hline Input3 & 6.2 & 0.36 & 130.0 & 0.62 & 3.59 \\
\hline Input4 & 5.8 & 0.36 & 92.5 & 0.40 & 3.27 \\
\hline
\end{tabular}

Note: Soil samples were taken out from Kolam Makmur, Sidomulyo and Simpangjaya.

Regarding to organic manure in the form of solid waste as well as liquid waste from factory were analyzed in ILETRI Soil Laboratory. Organic manure used in this trial was Manure2, due to it was chicken dunk with $\mathrm{N}$ Total was $2.59 \%$. In the chicken farm mostly farmers used lime and ash as well to avoid from flies, which have good effect for additional supplement of organic manure. While manure1 was originated from cattle, which mostly was fed by weeds. So, farmers worried that weed from seed would be grown after adequate environment. Seed of weeds are still alive under digest process of stomach of cattle. Unlike organic manure as solid waste, the liquid waste from seaweed alkali treated is used in this trial. The chemical used is $\mathrm{KOH}, \mathrm{KCl}$ and urea. As the liquid waste $\mathrm{KNO}_{3}$ was selected to be applied at $500 \mathrm{l}$ $\mathrm{ha}^{-1}$. Aside better chemical composition $\mathrm{KNO}_{3}$ was also higher in N organic, $\mathrm{N}-\mathrm{NH}_{4}, \mathrm{~N}-\mathrm{NO}_{3}, \mathrm{~N}-$ Total as well as $\mathrm{C}$ Organic and $\mathrm{pH}$ was 12.4 under alkaline criteria. In the acid soil Kolam Makmur and Sidamulya which $\mathrm{pH}$ is only around 4.3 additional of alkaline $\mathrm{KNO}_{3}$ with $\mathrm{pH} 12.4$ is better due to acid reduction. However this liquid $\mathrm{KNO}_{3}$ was heavier (specific gravity is 1.1) than did of water 1.0 (Table 3). 
Table 3. Manure used for experimentation in Batola South Borneo during 2015-2017.

\begin{tabular}{|c|c|c|c|c|c|c|c|c|}
\hline Sample & $\mathrm{pH}$ & $\mathrm{N}-$ & $\mathrm{N}-\mathrm{NH}_{4}$ & $\mathrm{~N}-\mathrm{NO}_{3}$ & $\mathrm{~N}-$ & C- Organic & \multicolumn{2}{|l|}{$\mathrm{P}$} \\
\hline & $\begin{array}{c}\mathrm{H} 2 \mathrm{O} \\
1: 5\end{array}$ & Organic & & & Total & Kurmis & \multicolumn{2}{|c|}{$\begin{array}{c}\text { Total Extraction } \\
\mathrm{HNO}_{3}-\mathrm{HClO}_{4}\end{array}$} \\
\hline Solid & & \multicolumn{7}{|c|}{ \%...................................... } \\
\hline Manure1 & 10.5 & 0.00 & 0.43 & 0.371 & 0.80 & 13.0 & 1.39 & 6.20 \\
\hline Manure2 & 7.8 & 1.96 & 0.17 & 0.462 & 2.59 & 23.8 & $5 \cdot 75$ & 3.22 \\
\hline Liquid & & \multicolumn{7}{|c|}{. } \\
\hline Fertilizer & 12.2 & 0.01 & 0.00 & 0.028 & 0.04 & 0.30 & 0.70 & 7.22 \\
\hline $\mathrm{KNO}_{3}$ & 12.4 & $15 \cdot 37$ & 1.32 & 1.799 & 18.49 & 0.44 & 0.70 & 1.56 \\
\hline
\end{tabular}

Note: $\mathrm{KNO}_{3}$ was from the factory of seaweed processing.

Sweet potato grown in tidal swampland

Of the total area in Barito Kuala (Batola) was motsly submerged by water especially in the type of $\mathrm{A}$ and $\mathrm{B}$, therefore sweet potato can be grown at tidal swamp of $\mathrm{C}$ and D. However, in 2016 due to huge of rainfall and in $\mathrm{C}$ type was submerged. Especially at the early growing period, flooding was submerged crop until 3 days. Under such of condition, growth of sweet potato was very suffered. Fortunately after flooding period the excessive growth of sweet potato was occur particularly variety Antin2. Consequently the vine growth was able to cover the area quickly. Unfortunately variety Antin2 was not able to indicate root yield as its potential. Because, under such condition growth was only produced from roots differentiated into pencil roots, not the tuberous root. Until harvest variety Antin2 was only produced the pencil roots. While Beta3 tended to normal, and tuber formation was not severely inhibited by the moisture content of soil. Due to excessive soil moisture content, therefore weevil (Cylas formicarius) infestation was not seriously occur. Weevil symptom was also revealed at the foliages of sweet potato that was attacked by weevil. Fortunately, due to wet and saturated condition therefore weevil was not moved to attack the tuber inside of underground portion. Moreover, Furadan $3 \mathrm{G}$ at amount of 25 $\mathrm{kg} \mathrm{ha}^{-1}$ was applied so it was absorbed to the crop and distributed to whole of tissue.

Indeed the effect of organic fertilizer was very good, tuber yield of Local variety was able to attain $9.72 \mathrm{t} \mathrm{ha}^{-1}$ while with Phonska $300 \mathrm{~kg} \mathrm{ha}^{-1}$ produced $9.85 \mathrm{t} \mathrm{ha}^{-1}$. However, when manure $5 \mathrm{t}$ $\mathrm{ha}^{-1}$ was applied with Phonska $300 \mathrm{~kg} \mathrm{ha}^{-1}$ as well as $500 \mathrm{l} \mathrm{ha}^{-1} \mathrm{KNO}_{3}$ yield did not increase (Table 4). In addition for Sidamulya, the highest tuber yield $7.19 \mathrm{t} \mathrm{ha}^{-1}$ was obtained by manure $5 \mathrm{t} \mathrm{ha}^{-1}$ with Phonska $300 \mathrm{~kg} \mathrm{ha}^{-1}$ as well as $500 \mathrm{l} \mathrm{ha}^{-1}$ $\mathrm{KNO}_{3}$. Tuber yield of sweet potato was related to soil pH in Sidamulya 4.3 and Kolam Makmur was 4.4 and Simpangjaya was 5.1 till 6.2 (Table 2).

From the results of 2017 revealed that growth of sweet potato very normal. There was not water logging in the area such as in 2016. Unfortunately at the end of growing period, the drought due to was no rain from Mid of May till June 2017. Although crop was treated by Furadan $3 \mathrm{G}$ at 25 $\mathrm{kg} \mathrm{ha}^{-1}$ however weevil was seriously attacked and was not applied for more insectiside due to period of time at near harvest. Among the insects, weevil is serious pest for sweet potato in tidal swampland. In the longrun Intergrated Pest Management should be practiced, so farmers did not depend on chemical control. Difficulty in controling weevil due to the larvae inside of tuber is felt by scentists, therefore research on this field is required. In this research, indeed weevil is seriously tackled by spraying spore of Beaveria basiana to infect the weevil into inside of cracking of soil. B. basiana is soil borne fungi which also effective for acid soil of sweet potato in Batola. In Papua New Guinea sweet potato is less damage due to weevil (Kapal et al., 2010). Kreuze et al. (2009) by genetic engineering weevil resistance can be developed with better culinary need. 
Table 4. Effect of canopy management and fertilizer application on sweet potato vine length, fresh vine weight and tuber yield at Tidal Swamp of C type. Batola South Borneo 2016.

\begin{tabular}{|c|c|c|c|c|c|c|}
\hline \multirow{2}{*}{ Treatment } & \multicolumn{3}{|c|}{ Kolam Makmur variety Local } & \multicolumn{3}{|c|}{ Sidamulya variety Beta3 } \\
\hline & $\begin{array}{l}\text { Vine } \\
\text { length } \\
\text { (cm) }\end{array}$ & $\begin{array}{c}\text { Fresh } \\
\text { vine } \\
\text { weight } \\
\left(\mathrm{t} \mathrm{ha}^{-1}\right)\end{array}$ & $\begin{array}{l}\text { Tuber } \\
\text { yield } \\
\left(\mathrm{t} \mathrm{ha}^{-1}\right)\end{array}$ & $\begin{array}{l}\text { Vine } \\
\text { length } \\
\text { (cm) }\end{array}$ & $\begin{array}{l}\text { Fresh } \\
\text { vine } \\
\text { weight } \\
\left(\mathrm{t} \mathrm{ha} \mathrm{a}^{-1}\right)\end{array}$ & $\begin{array}{l}\text { Tuber } \\
\text { yield } \\
\left(\mathrm{t} \mathrm{ha}^{-1}\right)\end{array}$ \\
\hline Canopy management & & & & & & \\
\hline $\begin{array}{l}\mathrm{C} 1=\text { mulching and canopy } \\
\text { did not care }\end{array}$ & $98.92 b$ & $10.54 a b$ & $10.01 b$ & $61.03 a$ & $16.12 \mathrm{a}$ & $6.82 \mathrm{ab}$ \\
\hline C2=canopy lifting twice & $93.85 \mathrm{ab}$ & $8.87 \mathrm{a}$ & $8.86 a b$ & $60.10 a$ & $16.14 \mathrm{a}$ & $5.15 \mathrm{~b}$ \\
\hline $\begin{array}{l}\text { C3=canopy were prunned } \\
30 \% \text { at } 2.5-3.0 \text { months }\end{array}$ & $92.83 a$ & $11.54 \mathrm{~b}$ & $8.45^{a}$ & $62.10 a$ & $15.58 \mathrm{a}$ & $4.74 \mathrm{c}$ \\
\hline LSD at $5 \%$ & 6.04 & 1.57 & 1.52 & NS & NS & 1.14 \\
\hline Fertilizer application & & & & & & \\
\hline $\mathrm{F} 1=5 \mathrm{t}$ manure $\mathrm{ha}^{-1}$ & $91.07 \mathrm{a}$ & $9.61 \mathrm{a}$ & $9.72 b$ & $59.51 \mathrm{a}$ & $15.71 \mathrm{a}$ & $5.03 \mathrm{bc}$ \\
\hline F2 $=300 \mathrm{~kg}$ Phonska ha-1 & $93.13 \mathrm{ab}$ & $10.67 \mathrm{ab}$ & $9.85 \mathrm{~b}$ & $59.31 \mathrm{a}$ & $15.69 \mathrm{a}$ & $5.35 \mathrm{~b}$ \\
\hline $\mathrm{F}_{3}=500 \mathrm{l} \mathrm{KNO} 3 \mathrm{ha}^{-1}$ & $99.98 \mathrm{c}$ & $9.63 a$ & 8.84ab & $62.33 \mathrm{a}$ & $16.80 \mathrm{a}$ & $4.75 \mathrm{c}$ \\
\hline $\mathrm{F}_{4}=\mathrm{F} 1+\mathrm{F} 2+\mathrm{F}_{3}$ & $96.62 b$ & $11.17 \mathrm{~b}$ & $8.00 \mathrm{a}$ & $63.15 \mathrm{a}$ & $15 \cdot 59 \mathrm{a}$ & $7.19 \mathrm{a}$ \\
\hline LSD at $5 \%$ & 5.47 & 1.39 & 1.36 & NS & NS & 1.26 \\
\hline CV (\%) & 16.84 & 33.80 & 13.19 & 14.36 & 15.70 & 22.01 \\
\hline
\end{tabular}

Note: Value in same colomn \& factor followed by the same letter did not differ significantly by Least Significant Difference (LSD) at $5 \%$ level.

Vine length, fresh vine weight as well as tuber yield of sweet potato were different due to canopy management. Mulching with weed till $5 \mathrm{t} \mathrm{ha}^{-1}$ to cover the ridges, then canopy of sweet potato leave out spreading was the most effective crop management. Vine lifting was not suitable due to overlap of vines, and immature leaves drop then produced new sprouting. Thus in producing the new sprouting means photosinthate goes to non tuberous root. Prunning is commonly done to manage the canopy of sweet potato, due to contact to soil and induces adventitious root, therefore prunning is done practically efficient. Unfortunately, yield of prunning as well as vine lifting is differed with sweet potato canopy did not care (Table 4). Statistical analysis indicated that there was not significantly affected by interaction between variety and agronomic inputs as well. However, both main and subplot were separately affected growth and yield. ILETRI variety Beta3 gave better yield $14.66 \mathrm{t} \mathrm{ha}^{-1}$ with agronomic input1 able to obtain $15.39 \mathrm{t} \mathrm{ha}^{-1}$. However, the increase of agronomic input did not follow the increase of tuber yield, except to vine fresh weight. In Israel the productivity of sweet potato in large area able to attain $40 \mathrm{t} \mathrm{ha}^{-1}$ with very good acceptance to market in Europe. Tuberous root will not deteriorated eventhough keep in storage till 3 months (Loebenstein et al., 2009). Unlike sweet potato in Israel, results of this research indicating poor quality of tuberous root, easy to rotten as well as deterioration. Nakazawa (2001) degeneration of sweet potato was also found in Japan due to virus. Smith and Villordon (2009) tried to modify fertilizer particularly $\mathrm{N}$ (Nitrogen), indeed the excessive $\mathrm{N}$ could be the cause of rotten in an acid soil of South Borneo.

Table 5. Effect of variety and agronomic input on sweet potato vine length, fresh vine weight and yield. Batola South Borneo 2017.

\begin{tabular}{|l|c|c|c|}
\hline Treatment & Vine lenght $(\mathrm{cm})$ & Fresh vines weight $\left(\mathrm{t} \mathrm{ha}^{-1}\right)$ & Tuber Yield $\left(\mathrm{t} \mathrm{ha}{ }^{-1}\right)$ \\
\hline Larieties & $108.0 \mathrm{a}$ & $8.64 \mathrm{a}$ & $10.72 \mathrm{a}$ \\
\hline Local & $172.9 \mathrm{~b}$ & $17.42 \mathrm{~b}$ & $14.66 \mathrm{~b}$ \\
\hline LSD at 5\% & 2.4 & 1.71 & 3.92 \\
\hline Inputs & & & $10.23 \mathrm{a}$ \\
\hline Farmers & $115.9 \mathrm{a}$ & $9.28 \mathrm{a}$ & $15 \cdot 39 \mathrm{~b}$ \\
\hline Input1 & $156.3 \mathrm{~d}$ & $16.72 \mathrm{c}$ & $13.72 \mathrm{ab}$ \\
\hline Input2 & $143.4 \mathrm{bcd}$ & $13.83 \mathrm{bc}$ & $11.50 \mathrm{a}$ \\
\hline Input3 & $151.1 \mathrm{bc}$ & $12.31 \mathrm{~b}$ & $12.49 \mathrm{ab}$ \\
\hline Input4 & $135.7 \mathrm{bcd}$ & $12.90 \mathrm{~b}$ & 3.54 \\
\hline LSD at 5\% & 7.9 & 2.10 & 21.12 \\
\hline Coefficient of & 15.83 & 27.49 & \\
\hline Variation $(\%)$ & & & \\
\hline
\end{tabular}

Note: Value in same colomn \& factor followed by the same letter did not differ significantly by Least Significant Difference (LSD) 5\% level. 


\section{Conclusion}

Based on the three years results, the conclusion can be presented are as follow:

- In Barito Kuala South of Borneo most of land is tidal swampland, and soil type is dominatedly Alluvial and Organosol. Texture of soil is clay with loamy. Soil organic matter is ranging form 1.00-4.06.

- In the year of 2016 due to high rainfall water logging was severely submerged the sweet potato trial till 3 days. Fortunately, yield of harvest in Sidamulyo ( $\mathrm{pH}$ 4.3) Beta3 was able to attain 4.75-7.19 $\mathrm{t} \mathrm{ha}^{-1}$ and in Kolam Makmur ( $\mathrm{pH}$ 4.4) Local was able to reach 8.00-9.75 $\mathrm{t} \mathrm{ha}^{-1}$. While Antin2 from Breeding Program was not able to produce the tuberous root yield.

- Both in producing high yield mulching with canopy not care was able to attain $10.01 \mathrm{t} \mathrm{ha}^{-1}$ in Kolam Makmur (pH 4.4) and 6.85 t ha-1 for Sidamulya ( $\mathrm{pH}$ 4.3). Producing tuber yield of $9.85 \mathrm{t} \mathrm{ha}^{-1}$ with $300 \mathrm{~kg}$ Phonska ha-1 in Kolam Makmur, however in Sidamulya $300 \mathrm{~kg}$ Phonska +5 t organic manure +500 $1 \mathrm{KNO}_{3} \mathrm{ha}^{-1}$ resulting $7.19 \mathrm{t} \mathrm{ha}^{-1}$ tuber yield, respectively.

- In Simpangjaya 2017 tuber yield of Beta3 was higher $14.66 \mathrm{t} \mathrm{ha}^{-1}$ than Local $10.72 \mathrm{t} \mathrm{ha}^{-}$ ${ }^{1}$. However, to produce high yield $15.39 \mathrm{t} \mathrm{ha}^{-1}$ Input1 was adequate.

\section{References}

Alvernas, J., Greenfield, D. and Hill, S. 2014. Growing sweet potato in the Sacramento area. UCCE Master Gardener of Sacramento County. University of California. USA. pp. 25 .

Anna, M.M., Kurnain, A., Ratna and Wahdah, R. 2015. Pioneering agriculture bioenergy: Geospatial analysis and soil quality evaluation of abandaned lands of tidal swamp. Acad. Res. Int. 6(2): 1-9.

Anthony, S. and Ramkissoon, A.N. 2011. Sweet potato nutrient requirements. Reference Materials Module 3. Project Consultant. 12p.

Bayliss-Smith, T., Golson, J. and Hughes, P. 2017. Phase 6: Impact of the sweet potato on swamp landuse pig rearing and exchange relationship. In: J. Golson, T. Demhan, P. Hughes, P. Swalding and J. Muke (Eds.) Ten Thousand Years of cultivation at Kuk swamp in the highland of Papua New Guinea. ANU Australia. pp. 1-28.

https://doi.org/10.22459/TA46.07.2017.16
BPS. 2017. Statistik Indonesia 2017. Badan Pusat Statistik. Tanggal Rilis 2017-07-04. Ukuran Jakarta. https://www. bps. go. id/site/resultTab (in Indonesian)

Firon, N., LaBonte, D., Villordon, A., McGregor, C., Kfir, Y. and Pressman, E. 2009. Botany and Physiology: Storage Root Formation and Development. In: G. Loebenstein and G. Thottappilly (Eds). The Sweet potato. Springer, Demand Germany. pp. 13-26. https://doi.org/10.1007/978-1-4020-9475-0_3

Kapal, D.B., Taraken, I.T. and Sirabis, W. 2010. Soil fertility management option in sweet potato based cropping in the highland of Papua New Guinea. In: $19^{\text {th }}$ World Congress of Soil Science Soil Solution for a Changing World, held on 1-10 August 2010. Brisbane, Australia. pp. 144-146. (Published on DVD).

Kreuze, J.F., Valkonen, J.P.T. and Ghislain, M. 2009. Genetic Engineering. In: G. Loebenstein and G. Thottappilly (Eds). The Sweet potato. pp. 41-63. Springer, Demand Germany. https://doi.org/10.1007/978-1-40209475-0_5

Loebenstein, G., Cohen, J. and Dar, Z. 2009. Sweet potato in Israel. In: G. Loebenstein and G. Thottappilly (Eds). The Sweet potato. pp. 483-487. Springer, Demand Germany. https://doi.org/10.1007/978-1-4020-9475-O_21

Nakazawa, Y. 2001. Report on the international workshop on sweet potato cultivar decline. Sweet potato Research Front. Kyushu National Agriculture Experiment Station (KNAES) held on 11 January 2001. pp. 1-2.

Purnomo, E., Setiawan, M.L., Yuliani, N., Atmaja, E., Wahyuni, M., Saidy, A.R. and Osaki, M. 2008. Local rice cultivars grown on tidal swampland near costal area in south kalimantan. J. Tanah Trop. 13(2): 103-109.

Smith, T.P. and Villordon, A.Q. 2009. Nitrogen Management in Lousiana Sweet Potatos. Lousiana State University Agricultural Center. Pub 3138. September 2009. 4p.

Virendra, M.V. 2014. Sweet potato cultivation guide. Micronesia Plant Propagation Research Centre Kosrae Agricultural Experiment Station Cooperative Research and Extension. College of Micronesia-FSM. $17 \mathrm{p}$.

Widjaja Adhi, I.P.G. 1986. Pengelolaan lahan rawa pasang surut dan lebak. J Penelitian dan Pengembangan Pertanian 1: 1-9. (in Indonesian). 